\title{
Development and Validation of a Short-Form Version of the Brazilian State-Trait Anxiety Inventory
}

\author{
Desenvolvimento e Validação da Forma Reduzida do Inventário \\ de Ansiedade Traço-estado
}

\author{
Ana Carolina Monnerat Fioravanti-Bastos ${ }^{a}$, Elie Cheniaux ${ }^{b, c} \&$ J. Landeira-Fernandez ${ }^{*}, a, d$ \\ ${ }^{a}$ Pontifícia Universidade Católica do Rio de Janeiro, Rio de Janeiro, Brasil \\ ${ }^{b}$ Universidade Federal do Rio de Janeiro, Rio de Janeiro, Brasil \\ 'Universidade do Estado do Rio de Janeiro Rio de Janeiro, Brasil \\ \& 'Universidade Estácio de Sá, Rio de Janeiro, Brasil
}

\begin{abstract}
The Brazilian State-Trait Anxiety Inventory has been widely used to measure state (STAI-S) and trait (STAI-T) components of anxiety. The present work developed and evaluated a short version of the STAI$\mathrm{S}$ and STAI-T in a large sample of Brazilian subjects. The first study selected short-form scales. The second one employed factor analyses to investigate whether each of the two short-form scales presented a well-defined and balanced structure with both anxiety-present and anxiety-absent factors. Results indicated that the STAI-S and STAI-T could be reduced to six items (STAI-S-6 and STAI-T-6, respectively) without sacrificing their psychometric properties. The findings suggest that STAI-S-6 and STAI-T-6 may be employed in situations where time restraints make the use of full-length forms unfeasible.

Keywords: Anxiety Assessment; State-trait Anxiety; Short-form Scales.
\end{abstract}

\begin{abstract}
Resumo
O inventário brasileiro de ansiedade traço-estado tem sido amplamente utilizado para medir os componentes de ansiedade, estado (STAI-S) e traço (STAI-T). O presente trabalho desenvolveu e avaliou uma versão simplificada de STAI-S e STAI-T em uma grande amostra de sujeitos brasileiros. O primeiro estudo selecionou as escalas de forma curta. O segundo estudo empregou análises fatorais para investigar se cada uma dessas duas escalas simplificadas apresentou uma estrutura bem definida e equilibrada com fatores de ansiedade-presente e ansiedade-ausente. Resultados indicaram que o STAI-S e o STAI-T poderiam ser reduzidos para seis itens (STAI-S-6 e STAI-T-6, respectivamente) sem comprometer suas propriedades psicométricas. Estes resultados sugerem que STAI-S-6 e STAI-T-6 podem ser empregados em situações onde restrições de tempo tornam inviável a utilização de formulários completos.

Palavras-chave: Avaliação de Ansiedade; Ansiedade Traço-estado; Escalas de Forma Simplificada.
\end{abstract}

The State-Trait Anxiety Inventory (STAI) is one of the most used self-report measures of anxiety in research and clinical settings across different cultures (Lonner \& Ibrahim, 1989). This instrument was developed by Spielberger, Gorsuch, and Lushene (1970) to provide an operational measure of two different components of anxiety: state and trait. State anxiety refers to a transitory emotional state characterized by subjective feelings or tension that may vary in intensity over time. Trait anxiety refers to a relatively stable disposition to respond to stress with anxiety and a tendency to perceive a wider range of situations as threatening (Cattell \& Scheier,

*Address: Pontifícia Universidade Católica do Rio de Janeiro, Departamento de Psicologia, Núcleo de Neuropsicologia Clínica e Experimental, Laboratório de Análise de Dados, Rua Marquês de São Vicente, 225, Rio de Janeiro, RJ, Brazil, CEP 22453-900. Tel: +55-213527-2075; Fax: +55-21-3527-1187. E-mail: landeira@puc-rio.br
1961). Accordingly, the STAI is composed of two different scales: one related to state anxiety (STAI-S) and one related to trait anxiety (STAI-T).

The STAI-S scale has 20 items that are answered on a 4-point Likert scale based on "how you feel right now, at this moment." Half of these items are positively worded (e.g., "I feel calm"), and the other half are negatively worded (e.g., "I feel tense"). The STAI-T scale also has 20 items that are answered on a different 4-point Likert scale based on "how do you generally feel." Seven of these items are positively worded (e.g., "I feel secure"), and the other 13 items are negatively worded (e.g., "I worry too much over something that really doesn't matter").

Although factor analysis studies have been controversial (Bieling, Antony, \& Swinson, 1998), they have revealed that both STAI scales have two factors (Barker, Barker, \& Wadsworth, 1977; Endler \& Magnusson, 1976; Endler, Magnusson, Ekehammer, \& Okada, 1976; 
Gaudry \& Poole, 1975; Loo, 1979; Spielberger, Vagg, Barker, Donham, \& Wetsberry, 1980). One of the STAI-S factors is related to the presence of anxiety (S-anxiety present) and includes all 10 negatively worded items. The other factor of this scale is associated with the absence of anxiety (S-anxiety absent) and includes all 10 positively worded items. Similarly, the STAI-T scale also has an anxiety-present factor (T-anxiety present) associated with the 13 negatively worded items and an anxiety absence factor (T-anxiety absent) associated with the seven positively worded items.

The original STAI, termed STAI-X, was revised by Spielberger, Gorsuch, Lushene, Vagg, and Jacobs (1983). This new version, referred to as STAI-Y, improved the specificity of the anxiety measure by replacing some of the original STAI items related to depression. The STAI$\mathrm{Y}$ also improved the structure of the STAI-T scale by achieving a better factor structure balance between anxiety-present and anxiety-absent items. Although the STAI-Y appears to have better psychometric properties compared with the STAI-X, both instruments appear to be comparable for anxiety assessment given that the correlation between them ranges between .96 and .98 (Spielberger et al., 1983).

Administering and scoring extended scales can take a considerable amount of time. Moreover, completing a long instrument might be tiresome and can lead to measurement error attributable to wrong or unanswered items (Schmidt, Le, \& Ilies, 2003). Consequently, developing a shortened version of a full-length scale is an important issue in research and clinical settings.

Previous studies consistently provided evidence that the STAI-S scale can be reduced to an abbreviated form. Marteau and Bekker (1992) developed the first short-form version of this scale. To preserve the S-anxiety present and S-anxiety absent dimensions of this scale, Marteau and Bekker (1992) selected three anxiety-present items and three anxiety-absent items. This 6-item short-form STAI-S scale produced scores similar to those observed with the full 20-item scale and has been widely used in clinical and basic research (Macaluso et al., 1996; Rose, Humm, Hey, Jones, \& Huson, 1999; Ubhi et al., 1996).

A short-form version of the STAI-S scale has also been developed for other languages, such as Japanese (Koizumi, Fujita, Ninomiya, \& Nakamoto, 1998), Dutch (van der Bij, de Weerd, Cikot, Steegers, \& Braspenning, 2003), and French (Micallef, McGlangeaud-Freudenthal, Aurran, \& Julian-Reynier, 1998). In each of these studies, a short-form version with 5 (Japanese version), 6 (Dutch version), or 8 (French version) items demonstrated good psychometric properties.

In Brazil, only the full-length STAI-X was initially translated into Portuguese by Biaggio and Natalício (1979). Since then, several studies were conducted to validate both the STAI-S and STAI-T scales in Brazilian populations (Andrade, Gorenstein, Vieira Filho, Tung, \& Artes, 2001; Fioravanti, Santos, Maissonette, Cruz, \& Landeira-Fernandez, 2006; Pasquali, Pinelli, \& Solha, 1994). However, no studies have attempted to develop a shortened version of the STAI-S and STAI-T scales. Therefore, the purpose of the present study was to develop a short form of these two STAI scales with acceptable psychometric properties in a Brazilian population.

Typically, the construction of a short-form version of an existing instrument considers the internal consistency and reliability based on item-total correlation. However, short-form scales must have the same factor structure of the full-length scale (Smith, McCarthy, \& Anderson, 2000). Following this guidance, a first study was performed to select the items with the best item-total correlation representing the STAI factor structure. A second study employed factor analysis to investigate whether the factor structure of the short-form STAI scales are equivalent to their respective full-length scales in a different subset of subjects.

\section{Method}

\section{Participants}

A group of 4.455 subjects from five different samples participated in this study. The five samples included 1.173 high school students from Rio de Janeiro, 1.240 high school students from Niterói, 1.328 university students from Rio de Janeiro, 317 university students from Santa Catarina, and 397 employees of a public hospital and private company, both in Rio de Janeiro. Each of these samples was randomly divided into two subsets to perform the two studies of the present report. Table 1 presents the age and gender distribution of these five samples used in the first and second studies.

Table 1

Age and Gender Distribution of the Five Samples Used in the Present Study

\begin{tabular}{lcc}
\hline Sample & Age mean (SD) & Gender (male / female) \\
\hline High school students from Rio de Janeiro & $23.6(10.2)$ & $613 / 560$ \\
High school students from Niterói & $15.7(0.9)$ & $576 / 665$ \\
University students from Rio de Janeiro & $23.7(6.3)$ & $526 / 802$ \\
University students from Santa Catarina & $22.9(7.7)$ & $90 / 227$ \\
Employers from a public hospital and a private company & $27.6(11.2)$ & $154 / 243$ \\
\hline
\end{tabular}




\section{Instrument}

Both studies used the 20 state and 20 trait anxiety items from the STAI-X and the six new items from each scale of the STAI-Y, providing a 26 item state scale and a 26 item trait scale. The 12 new items were translated into Portuguese by two translators and then back-translated to English by two other translators who had not seen the original items. This back translation was then compared with the original English items by one of the authors. This took into consideration linguistic and semantic equivalence between translations. Afterward, a pilot study indicated that all subjects were able to perfectly understand the 12 new items of the STAI scales.

The state scale required the participant to describe how he or she feels at "this very moment" in relation to 26 items presented on a 4-point Likert intensity scale: $1=$ "not at all," 2 = "somewhat," 3, = "moderately," 4 = "very much." The trait scale required the participant to describe how he or she "generally" feels in relation to the 26 items presented on the same 4-point Likert scale.

\section{Procedure}

All subjects were invited to participate in the study and were informed of the nature of the study. High school and undergraduate students answered the instrument in a group setting that varied between 10 and 50 participants during their regular class schedule. Hospital and company employees answered the instrument alone during customary working hours. Questionnaires were completed with no time limit. None of the participants demonstrated difficulty in understanding either the instructions or any of the items. Subjects took between 15 to $30 \mathrm{~min}$ to complete the scales. No payment or course credits were offered to the subjects.

\section{Statistical Analysis}

The purpose of the first study was to choose the optimal short forms of the STAI-S and STAI-T scales. The item selection procedure was based on the statistical methodology reported by Marteau and Bekker (1992). According to this procedure, items from the STAI-S and STAI-T scales were ranked according to their corrected item-total correlation scores. Based on this parameter, an equal number of anxiety-present and anxiety-absent items were selected to create 10-, 8-, 6-, and 4-item forms of the STAI-S and STAI-T scales. Subsequently, internal consistency of each of the four short-form versions was assessed by calculating their respective Cronbach a coefficients. Accepted Cronbach $\alpha$ coefficients are usually higher than .7 (Nunnally \& Bernstein, 1994). Pearson correlation coefficients between each of the four short-form and full-length scales were calculated to evaluate the similarity between the short-form and fulllength scales. A correlation value within .9 is generally acceptable as a good indication of proportionality between scales (Kline, 1993). The second study evaluated in a new subset of subjects the internal consistency and factor structure of the short version of the STAI-S and STAI-T scales derived from the first study. Factor structure was evaluated by a principal axis factor analysis with varimax rotation. The number of factors was determined based on (a) the number of eigenvalues greater than 1, (b) examination of the scree plot of the eigenvalues against the number of factors, and (c) the interpretability of the factors.

\section{Results}

\section{Study 1. Choosing the Optimal STAI-S and STAI-T Short-form Scales}

STAI-S. To select the best items of the STAI-S scale, items were ranked according to their corrected item-total correlation coefficients (Table 2). With the exception of item 10, all items presented values above the .3 cut-off criteria suggested by Nunnally and Bernstein (1994), indicating the good association of these items with the total score of the STAI-S.

Based on these corrected item-total correlation coefficients, four short-version STAI-S scales were formed. Accordingly, a 10-item scale (STAI-S-10) was composed of the five anxiety-present and five anxietyabsent items with the highest corrected item-total correlation coefficients (anxiety-present items: 17, 3, 12, 25, and 14; anxiety-absent items: 1, 15, 5, 20, and 26). Eight-item (STAI-S-8), 6-item (STAI-S-6), and 4-item (STAI-S-4) scales were also formed, always selecting half of the anxiety-present and half of the anxiety-absent items with the highest corrected item-total correlation coefficients.

Table 3 depicts the Cronbach $\alpha$ coefficients for each of the four short-form scales with balanced positively and negatively worded items. Table 3 also presents the correlation between scores from each of these four shortform scales with the scores of the full-length STAI-S scale. As expected, both the Cronbach's $\alpha$ coefficients and shortform and full-length scale correlation coefficients were proportional to the number of items from each of the shortform scales. According to these results, the STAI-S-6 presented the lower number of items with acceptable Cronbach $\alpha$ coefficients and good correlation coefficients with its full-length form. 
Table 2

Corrected Item-total Correlations of the STAI-S Scale. Correlations in Bold Indicate the Five Higher Positively (P) and Negatively $(N)$ Worded Items

\begin{tabular}{|c|c|c|c|}
\hline \multicolumn{2}{|c|}{ State anxiety items } & \multirow{2}{*}{$\begin{array}{c}\text { Nature } \\
\mathrm{N}\end{array}$} & \multirow{2}{*}{$\begin{array}{l}\begin{array}{l}\text { Corrected item-total } \\
\text { correlation }\end{array} \\
\mathbf{. 6 2}\end{array}$} \\
\hline 17 & I am worried & & \\
\hline & Estou preocupado(a) & & \\
\hline \multirow[t]{2}{*}{3} & I am tense & $\mathrm{N}$ & .59 \\
\hline & Estou tenso(a) & & \\
\hline \multirow[t]{2}{*}{12} & I feel nervous & $\mathrm{N}$ & .58 \\
\hline & Sinto-me nervoso (a) & & \\
\hline \multirow[t]{2}{*}{25} & I feel confused & $\mathrm{N}$ & .58 \\
\hline & Sinto-me confuso(a) & & \\
\hline \multirow{2}{*}{14} & I feel high strung & $\mathrm{N}$ & .57 \\
\hline & Sinto-me uma pilha de nervos & & \\
\hline \multirow[t]{2}{*}{18} & I feel over-exited and "rastled" & $\mathrm{N}$ & .57 \\
\hline & Sinto-me superexitado (a) e confuso (a) & & \\
\hline \multirow[t]{2}{*}{23} & I feel frigtened & $\mathrm{N}$ & .55 \\
\hline & Sinto-me assustado(a) & & \\
\hline \multirow[t]{2}{*}{1} & I feel calm & $\mathrm{P}$ & .53 \\
\hline & Sinto-me calmo(a) & & \\
\hline \multirow[t]{2}{*}{6} & I feel upset & $\mathrm{N}$ & .52 \\
\hline & Sinto-me perturbado(a) & & \\
\hline \multirow[t]{2}{*}{15} & I am relaxed & $\mathrm{P}$ & .50 \\
\hline & Estou descontraído(a) & & \\
\hline \multirow[t]{2}{*}{7} & I am presently worrying over possibles misfortunes & $\mathrm{N}$ & .50 \\
\hline & Estou preocupado(a) com possíveis infortúnios & & \\
\hline \multirow[t]{2}{*}{5} & I feel at easy & $\mathrm{P}$ & .50 \\
\hline & Sinto-me à vontade & & \\
\hline \multirow[t]{2}{*}{20} & I feel pleasant & $\mathrm{P}$ & .49 \\
\hline & Estou bem & & \\
\hline \multirow[t]{2}{*}{9} & I feel anxious & $\mathrm{N}$ & .48 \\
\hline & Sinto-me ansioso (a) & & \\
\hline \multirow{2}{*}{21} & I feel strained & $\mathrm{N}$ & .48 \\
\hline & Sinto-me pressionado(a) & & \\
\hline \multirow[t]{2}{*}{24} & I feel indecisive & $\mathrm{N}$ & .47 \\
\hline & Sinto-me indeciso(a) & & \\
\hline \multirow[t]{2}{*}{26} & I feel steady & $\mathrm{P}$ & .47 \\
\hline & Sinto-me equilibrado(a) & & \\
\hline \multirow[t]{2}{*}{19} & I feel joyfull & $\mathrm{P}$ & .45 \\
\hline & Sinto-me alegre & & \\
\hline \multirow[t]{2}{*}{22} & I feel satisfied & $\mathrm{P}$ & .45 \\
\hline & Sinto-me satisfeito $(a)$ & & \\
\hline 11 & I feel self-confident & $\mathrm{P}$ & .42 \\
\hline & Sinto-me confiante & & \\
\hline 16 & I feel content & $\mathrm{P}$ & .42 \\
\hline & Sinto-me completo $(a)$ & & \\
\hline 4 & I am regretfull & $\mathrm{N}$ & .37 \\
\hline & Estou arrependido(a) & & \\
\hline 13 & I am jittery & $\mathrm{N}$ & .36 \\
\hline & Estou agitado(a) & & \\
\hline 2 & I feel secure & $\mathrm{P}$ & .32 \\
\hline & Sinto-me seguro(a) & & \\
\hline 8 & I feel rested & $\mathrm{P}$ & .30 \\
\hline & Sinto-me descansado(a) & & \\
\hline 10 & I feel confortable & $\mathrm{P}$ & .19 \\
\hline & Sinto-me em casa & & \\
\hline
\end{tabular}


Fioravanti-Bastos, A. C. M., Cheniaux, E. \& Landeira-Fernandez, J. (2011). Development and Validation of a Short-Form Version of the Brazilian State-Trait Anxiety Inventory.

Table 3

Cronbach a Coefficients and Full-length and Short-form Version Correlations of Four Short Versions of the STAI-S Scale

\begin{tabular}{lcc}
\hline Short STAI-S version & Cronbach $\alpha$ & Full and short version correlation \\
\hline STAI-S-10 & .83 & .95 \\
STAI-S-8 & .80 & .93 \\
STAI-S-6 & .75 & .90 \\
STAI-S-4 & .67 & .86 \\
\hline
\end{tabular}

STAI-T. Similar to the STAI-S scale, items from the STAI-T scale were also ranked according to its corrected item-total correlation coefficients. As shown in Table 4, all but item 14 presented values above the .3 cut-off criteria suggested by Nunnally and Bernstein (1994), indicating the good association of these items with the total score of the STAI-T scale.

Table 4

Corrected Item-total Correlations of the STAI-T Scale. Correlations in Bold Indicate the Five Higher Positively (P) and Negatively (N) Worded Items

\begin{tabular}{rr}
\hline State anxiety items & Corrected \\
& Naturem-total \\
& correlation \\
\hline
\end{tabular}

13

I feel secure

$\mathrm{P}$

.55

Sinto-me uma pessoa segura

9 I worry too much over something that really doesn't matter

$\mathrm{N}$

.52

Preocupo-me demais com coisas sem importância

21 I feel nervous and restless

$\mathrm{N}$

.51

Sinto-me nervoso(a) e inquieto(a)

20 I get in a state of tension or turmoil as I think over my recent concerns and interests $\mathrm{N}$ Fico tenso(a) e perturbado(a) quando penso em meus problemas no momento

$7 \quad$ I am calm, cool and collected

Sou calmo(a), ponderado(a) e senhor de mim mesmo(a)

11 I am inclined to take things hard

Deixo-me afetar muito pelas coisas

$25 \quad$ I make decisions easily

$\mathrm{N}$

Tomo decisões facilmente

12 I lack self-confidence

Não tenho muita confiança em mim mesmo(a)

8 I feel that difficulties are piling up so that I can not overcome them $\mathrm{N}$

Sinto que as dificuldades vão se acumulando de tal forma que não consigo resolver

16 I am content

Sinto-me uma pessoa completa

23 I feel like a failure

Sinto-me um(a) fracassado(a)

15 I feel blue

Sinto-me deprimido(a)

3 I feel like crying

Tenho vontade de chorar

18 I take desappoitments so keenly that I can't put them out of my mind

Levo os desapontamentos tão á sério que não consigo tirá-los da cabeça

10 I am happy

$\mathrm{N}$

Sou feliz

$4 \quad$ I wish I could be as happy as others seem to be

Gostaria de poder ser tão feliz quanto os outros parecem ser 
22 I feel satisfied myself

Sinto-me satisfeito(a) comigo mesmo(a)

17 Some unimportant thoughts runs through my mind and bothers me Às vezes, idéias sem importância me entram na cabeça e ficam me preocupando

19 I am a steady person Sou uma pessoa estável

24 I have disturbing thoughts Eu tenho pensamentos perturbadores

5 I am losing out on things because I can't make up mind soon enough Perco oportunidades porque não consigo tomar decisões rapidamente

1 I feel pleasant Sinto-me bem

26 I feel inadequate Sinto-me deslocado(a)

2 I tire quickly Canso-me facilmente

$6 \quad$ I fell rested Sinto-me descansado(a)

14 I try to avoid facing crises or difficulty Evito ter que enfrentar crises ou problemas
$\mathrm{N}$
Table 5 presents the Cronbach $\alpha$ coefficients and correlations with the full-length STAI-T scale of the 10item (STAI-T-10), 8-item (STAI-T-8), 6-item (STAIT-6), and 4-item (STAI-T-4) scales with the best balanced anxiety-present and anxiety-absent items of the STAI-T scale with higher corrected item-total correlation coefficients (anxiety-present items: 9, 21, 20, 11, and 12; anxiety-absent items: $13,7,25,16$, and 10). As shown in Table 4, the 26 items of the STAI-T scale could be reduced to a 6-item scale with good Cronbach a coefficients and accep-table correlation coefficients with its full-length form.

Table 5

Cronbach $\alpha$ Coefficients and Full-length and Short-form Version Correlations of Four Short-form Versions of the STAI-T Scale

\begin{tabular}{lcc}
\hline Short STAI-S version & Cronbach $\alpha$ & Full and short version correlation \\
\hline STAI-T-10 & .81 & .93 \\
STAI-T-8 & .78 & .92 \\
STAI-T-6 & .73 & .89 \\
STAI-T-4 & .65 & .83 \\
\hline
\end{tabular}

Study 2. Evaluation of the STAI-S and STAI-T

Short-form Scales

STAI-State. The factor structure of the STAI-S-6 scale was evaluated by a principal axis factor analysis with varimax rotation. Analysis of eigenvalues and scree plot and interpretability of the factors indicated a two-factor solution. The rotated factor loading for this two-factor solution is presented in Table 6 . The first factor was responsible for $39.8 \%$ of the variance, with an eigenvalue of 2.4. This factor was consistent with the anxiety-present interpretation and incorporated all three items related to this construct. The other factor explained $17.9 \%$ of the variance, with an eigenvalue of 1.1. This factor was consistent with an anxiety-absent interpretation, which includes all three items associated with this construct.
Table 6

Principal Axis Factor Analysis Loading of the STAI-S-6 Scale Items Following Varimax Rotation

\begin{tabular}{lcc}
\hline \multirow{2}{*}{ State anxiety items } & \multicolumn{2}{c}{ Factors } \\
\cline { 2 - 3 } & I & II \\
\hline 17 & $\mathbf{. 8 4}$ & .13 \\
3 & $\mathbf{. 7 8}$ & .19 \\
12 & $\mathbf{. 6 5}$ & .25 \\
5 & .08 & $\mathbf{. 8 2}$ \\
1 & .22 & $\mathbf{. 7 1}$ \\
15 & .28 & $\mathbf{. 6 4}$
\end{tabular}


Fioravanti-Bastos, A. C. M., Cheniaux, E. \& Landeira-Fernandez, J. (2011). Development and Validation of a Short-Form Version of the Brazilian State-Trait Anxiety Inventory.

STAI-Trait. The factor structure of the STAI-T-6 scale was also evaluated by a principal axis factor analysis with varimax rotation. Again, analysis of eigenvalues and scree plot and interpretability of the factors indicated a twofactor solution. Table 6 presents the rotated factor loading for a two-factor solution. A well-defined structure of two factors (anxiety-present and anxiety-absent) was found. The first factor was responsible for $41.4 \%$ of the variance, with an eigenvalue of 2.5. The other factor explained $14.2 \%$ of the variance, with an eigenvalue of 0.86 . As shown in Table 7, all six items had salient loadings in a single factor exclusively.

Table 7

Principal Axis Factor Analysis Loading of the STAI-T-6 Scale Items Following Varimax Rotation

\begin{tabular}{rrr}
\hline \multirow{2}{*}{ Trait anxiety items } & \multicolumn{2}{c}{ Factors } \\
\cline { 2 - 3 } & $\mathrm{I}$ & II \\
\hline 7 & $\mathbf{8 0}$ & .13 \\
13 & $\mathbf{. 7 5}$ & .21 \\
25 & $\mathbf{. 6 1}$ & .25 \\
21 & .11 & $\mathbf{. 8 1}$ \\
20 & .25 & $\mathbf{. 6 9}$ \\
9 & .23 & $\mathbf{. 6 3}$ \\
\hline
\end{tabular}

\section{Normative Data}

To provide normative data for the STAI-S-6 and STAIT-6, all cases from study 1 and 2 were combined. Male and female scores in both scales are presented separately because of the fact that females presented statistically higher scores compared with males in both scales (STAI-S-6: $t_{4453}=6.67, p<.001$; STAI-T-6: $t_{4453}=6.49$, $p<.001)$. Table 8 summarizes the means, standard deviations (SD), and percentile distributions according to the gender of the subjects.

Table 8

Normative Data (mean, standard deviation, $10^{\text {th }}$ and $90^{\text {th }}$ percentile) of the STAI-S-6 (top) and STAI-T-6 (bottom) for Males, Females, and Total Sample

\begin{tabular}{|c|c|c|c|c|c|c|c|}
\hline \multirow{2}{*}{$\begin{array}{l}\text { Short-form } \\
\text { scale }\end{array}$} & \multirow{2}{*}{ Sample } & \multirow{2}{*}{ Mean } & \multirow{2}{*}{$S D$} & \multicolumn{2}{|c|}{ 10th percentile } & \multicolumn{2}{|c|}{ 90th percentile } \\
\hline & & & & score & percentage & score & percentage \\
\hline \multirow[t]{3}{*}{ STAI-S-6 } & Male & 12.2 & 3.6 & 8 & 16.2 & 17 & 12.1 \\
\hline & Female & 12.9 & 3.6 & 8 & 11.2 & 18 & 11.9 \\
\hline & Total & 12.6 & 3.6 & 8 & 13.4 & 18 & 10.1 \\
\hline \multirow[t]{3}{*}{ STAI-T-6 } & Male & 12.0 & 3.7 & 7 & 10.1 & 17 & 12.2 \\
\hline & Female & 12.8 & 3.6 & 8 & 11.3 & 18 & 10.7 \\
\hline & Total & 12.4 & 3.7 & 8 & 14.3 & 17 & 14.6 \\
\hline
\end{tabular}

\section{Discussion}

The present study presents the first attempt to develop and validate a short-form version of the Brazilian STAI. Based on the present results, both the STAI-S and STAI$\mathrm{T}$ could be reduced to 6-item short-form scales without jeopardizing their psychometric properties. The STAI-S6 (see Appendix A, top) presented acceptable internal consistency and a well-defined and balanced structure with both anxiety-present and anxiety-absent factors. These results are consistent with previous reports that also found good psychometric properties in a STAI-S short form (Koizumi et al., 1998; Marteau \& Bekker, 1992; Micallef et al., 1998; van der Bij et al., 2003).

Findings from the present work also indicated that the Portuguese STAI-T-6 (see Appendix A, bottom) had an adequate internal consistency coefficient and a welldefined factor structure with three anxiety-present items and three anxiety-absent items. To our knowledge, this is the first evidence that the full version of the STAI-T scale can be reduced to a 6 -item scale. Therefore, the present STAI-T-6 also appears to be a reliable and valid instrument to measure trait anxiety. 
Importantly, reducing the length of the STAI eliminated subtle items associated with depression. In fact, several reports indicated that one of the factors of the full version of the STAI-T is related to depression (Andrade et al., 2001; Bieling et al., 1998). The fact that both STAI scales can be shortened to six items and still preserve their psychometric properties represents a valuable alternative in research and clinical settings. Short-form scales have several advantages. For example, they tend to reduce response bias, which is more likely to occur with long and time-consuming scales. Moreover, short forms are much easier to use, especially in clinical contexts where time pressure precludes the use of full-length scales.

Although the present study concluded that both STAI$\mathrm{S}$ and STAI-T could be reduced to six items without sacrificing their psychometric properties, it is important to acknowledge that there were several limitations that can be addressed in future research. For example, convergent validity of the STAI-S-6 and STAI-T-6 could be investigated if the study had another anxiety instrument. In the same vein, it would be important to use a depression scale, such as the Beck Depression Inventory, so that the STAI-S-6 and STAI-T-6 divergent validity could be evaluated. Moreover, the fact that the five samples were composed mainly by young subjects might have lessened the representativeness of the sample which, in turn, could limit the generalizability of present findings. Finally, the presence of a clinical sample diagnosed with anxiety disorders would be particularly important to evaluate the factor structure of the STAI-S6 and STAI-T-6 in a psychopathological context. A clinical sample would also allow describing cut-off scores which would help to employ the short form of these two STAI scales as screening instrument for anxiety disorders. Therefore, future work taking into consideration these variables will certainly help to further evaluate the utility of the STAI-S-6 and STAI-T-6 scales.

\section{References}

Andrade, L., Gorenstein, C., Vieira Filho, A. H., Tung, T. C., \& Artes, R. (2001). Psychometric properties of the Portuguese version of the State-Trait Anxiety Inventory applied to college students: Factor analysis and relation to the Beck Depression Inventory. Brazilian Journal of Medical and Biological Research, 34, 367-374.

Barker, B. M., Barker, H. R., Jr., \& Wadsworth, A. P. (1977). Factor analysis of the State-Trait Anxiety Inventory. Journal of Clinical Psychology, 33, 450-455.

Biaggio, A. M. B., \& Natalício, L. (1979). Manual para o Inventário de Ansiedade Traço-Estado (IDATE). Rio de Janeiro, RJ: Centro Editor de Psicologia Aplicada.

Bieling, P. J., Antony, M. M., \& Swinson, R. P. (1998). The State-Trait Anxiety Inventory, Trait version: Structure and content re-examined. Behavior Research and Therapy, 36, 777-788.
Cattell, R. B., \& Scheier, I. H. (1961). The meaning and measurement of neuroticism and anxiety. New York: Ronald Press.

Endler, N. S., \& Magnusson, D. (1976). Multidimentional aspects of state and trait anxiety: A crosscultural study of Canadian and Swedish college students. In C. D. Spielberger \& R. Diaz-Guerrero (Eds.), Cross-cultural anxiety (pp. 143172). Washington, DC: Hemisphere.

Endler, N. S., Magnusson, D., Ekehammer, B., \& Okada, M. (1976). The multi-dimentionality of state and trait anxiety. Scandinavian Journal of Psychology, 17, 81-96.

Fioravanti, A. C. M., Santos, L. F., Maissonette, S., Cruz, A. P. M., \& Landeira-Fernandez, J. (2006). Avaliação da estrutura fatorial da escala de ansiedade-traço do IDATE. Avaliação Psicológica, 5, 217-224.

Gaudry, E., \& Poole, C. (1975). A further validation of the statetrait distinction in anxiety research. Australian Journal of Psychology, 27, 119-125.

Kline, P. (1993). A handbook of test construction: Introduction to psychometric design. London: Routledge.

Koizumi, N., Fujita, D., Ninomiya, R., \& Nakamoto, N. (1998). Screening test by statistically reducing the number of the State-Trait Anxiety Inventory (STAI) items. Sangyo Eiseigaku Zasshi, 40, 107-112.

Lonner, W. J., \& Ibrahim, F. A. (1989). Assessment in crosscultural counseling. In P. B. Pedersen, J. C. Draguns, W. J. Lonner, \& J. E. Trimble (Eds.), Counseling across cultures ( $3^{\text {rd }}$ ed., pp. 299-333). Honolulu, HI: University of Hawaii Press.

Loo, R. (1979). The State-Trait Anxiety Inventory A-trait scale: Dimensions and their generalization. Journal of Personality Assessment, 43, 50-53.

Marteau, T. M., \& Bekker, H. (1992). The development of a six-item short-form of the state scale of the Spielberger StateTrait Anxiety Inventory (STAI). British Journal of Clinical Psychology, 31, 301-306.

Macaluso, A. D., Connelly, A. M., Hayes, W. B., Holub, M. C., Ramsay, M. A., Suit, C. T., et al. (1996). Oral transmucosal fentanyl citrate for premedication in adults. Anesthesia and Analgesia, 82, 158-161.

Micallef, J., McGlangeaud-Freudenthal, N., Aurran, Y., \& Julian-Reynier, C. (1998). Measurement of anxiety state in women: A short-form scale. Revue d'Epidemiologie et de Sante Publique, 46, 383-389.

Nunnally, J., \& Bernstein, I. (1994). Psychometric theory. New York: McGraw-Hill.

Pasquali, L., Pinelli, B., Jr., \& Solha, A. C. (1994). Contribuição à validade e normatização da escala de ansiedade traçoestado do IDATE. Psicologia: Teoria e Pesquisa, 10, 411420.

Rose, P., Humm, E., Hey, K., Jones, L., \& Huson, S. M. (1999). Family history taking and genetic counselling in primary care. Family Practice, 16, 78-83.

Schmidt, F. L., Le, H., \& Ilies, R. (2003). Beyond alpha: An empirical examination of the effects of different sources of measurement error on reliability estimates for measures of individual differences constructs. Psychological Methods, 8 , 206-224.

Smith, G. T., McCarthy, D. M., \& Anderson, K. G. (2000). On the sins of short-form development. Psychological Assessment, 12, 102-111. 
Fioravanti-Bastos, A. C. M., Cheniaux, E. \& Landeira-Fernandez, J. (2011). Development and Validation of a Short-Form Version of the Brazilian State-Trait Anxiety Inventory.

Spielberger, C. D., Gorsuch, R. C., \& Lushene, R. E. (1970). Manual for the State Trait Anxiety Inventory. Palo Alto, CA: Consulting Psychologists Press.

Spielberger, C. D., Gorsuch, R., Lushene, R., Vagg, P. R., \& Jacobs, G. A. (1983). Manual for the State-Trait Anxiety Inventory (Form Y). Palo Alto, CA: Consulting Psychologists Press.

Spielberger, C. D., Vagg, P. R., Barker, L. R., Donham, G. W., \& Wetsberry, L. G. (1980). The factor structure of the StateTrait Anxiety Invetory. In I. G. Sarason \& C. D. Spielberger (Eds.), Stress and anxiety (Vol. 7, pp. 95-109). Washington, DC: Hemisphere.

Ubhi, S. S., Shaw, P., Wright, S., Stotter, A., Clarke, L., Windle, R., et al. (1996). Anxiety in patients with symptomatic breast disease: Effects of immediate versus delayed communication of results. Annals of the Royal College of Surgeons of England, 78, 466-469.

van der Bij, A. K., de Weerd, S., Cikot, R. J., Steegers, E. A., \& Braspenning, J. C. (2003). Validation of the Dutch short form of the state scale of the Spielberger State-Trait Anxiety Inventory: Considerations for usage in screening outcomes. Community Genetics, 6, 84-87. 


\section{Appendix A}

Portuguese version of the STAI-S-6 (top) and STAI-T-6 (bottom)

Nome Data da aplicação

Idade Estado Civil Sexo

Nível de instrução Profissão

\section{PARTE I}

Leia cada afirmativa abaixo e faça um círculo ao redor do número que melhor indique como você se sente AGORA, neste momento. Não gaste muito tempo numa única afirmação, mas tente dar uma resposta que mais se aproxima de como você se sente NESTE MOMENTO

\section{AVALIAÇÃO}

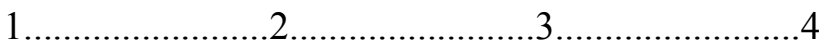

\section{Absolutamente não Umpouco Bastante Muitíssimo}

1- Sinto-me calmo(a) $\begin{array}{llll}1 & 2 & 3 & 4\end{array}$

2- Estou tenso(a) $\begin{array}{llll}1 & 2 & 3 & 4\end{array}$

3- Sinto-me à vontade. $\begin{array}{llll}1 & 2 & 3 & 4\end{array}$

4- Sinto-me nervoso(a).

5- Estou descontraído(a). $\begin{array}{llll}1 & 2 & 3 & 4\end{array}$

6- Estou preocupado(a) $\begin{array}{llll}1 & 2 & 3 & 4\end{array}$

$\begin{array}{llll}1 & 2 & 3 & 4\end{array}$

\section{PARTE II}

Leia cada afirmativa abaixo e faça um círculo ao redor do número que melhor indique como você GERALMENTE se sente. Não gaste muito tempo numa única afirmação, mas tente dar uma resposta que mais se aproxima de como você se sente GERALMENTE

\section{AVALIAÇÃo}

Quase nunca $\quad$ Às vezes $\quad$ Frequentemente Quase sempre

1- Sou calmo(a), ponderado(a) e senhor(a) de mim mesmo(a)............. $1 \quad 2 \quad 3 \quad 4$

2- Preocupo-me demais com coisas sem importância........................ $1 \begin{array}{llll}1 & 2 & 3 & 4\end{array}$

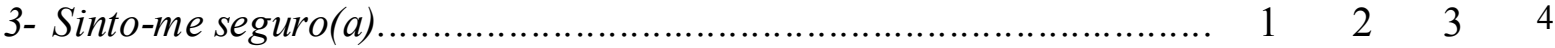

4- Fico tenso(a) e perturbado(a) quando penso em meus

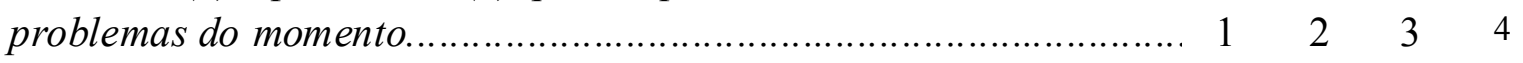

5- Sinto-me nervoso(a) e inquieto(a)....................................... $1 \quad 2 \quad 3 \quad 4$

6- Tomo decisões facilmente................................................... $1 \quad 2 \quad 3 \quad 4$ 